\title{
The Effects of Board Compositions and Audit Committee Characteristics on Information Disclosure Practices: A Case of Singapore
}

\author{
Nunthapin Chantachaimongkol (Corresponding author)
}

Department of Management and Economics, Dalian University of Technology, Dalian, China

Shuwen Chen

Department of Management and Economics, Dalian University of Technology, Dalian, China

Received: April 7, 2018 Accepted: June 27, $2018 \quad$ Published: June 27, 2018

doi:10.5296/ajfa.v10i1.13261ＵRL: https://doi.org/10.5296/ajfa.v10i1.13261

\begin{abstract}
This paper aims to investigate the effects of board compositions and audit committee characteristics on disclosure practices in Singapore. The ASEAN Disclosure Index, covering 212 items in 3 domains: Financial Information, Non-Financial Information, and Strategic Management Information, was constructed to capture disclosed information of 22 listed companies from 2011-2015, made out of 110 observations. In the analytical procedure, multiple regression models were tested through EVIEWS 10 with an ordinary least squares (OLS) method to estimate the connection between the predictors and the dependent variable. An empirical result reports that board size, audit committee independence, a number of audit committee meetings and a number of audit committee participation rates have a positive relationship with the level of corporate disclosure while CEO duality has a negative association with information disclosure practices. For other variables covering board independence, a number of board meetings, a number of director participation rates and gender diversity, no significant relationship was found. The findings might help regulators in enhancing the level of corporate disclosure in Singapore as well as neighboring countries in Southeast Asia region. Furthermore, this study also contributes to the literature by offering a new instrument for assessing the extent of corporate disclosure in Southeast Asia region and also providing some insight into the relationship between corporate governance mechanisms on information disclosure practices based on the Asia's developed country perspective.
\end{abstract}

Keywords: Corporate governance, Board of Directors, Audit Committee, Information Disclosure, Singapore 


\section{Introduction}

Over the last few decades, the research frontier in corporate disclosure has been enlarged in both scope and quality. Several types of research have been conducted a research to investigate the determinants of corporate disclosure in various aspects around the world. This includes an observation of the relationship between corporate governance mechanisms and information disclosure practices in the association of Southeast Asian Nations (ASEAN). For instance, a study of Zainon et al. (2014) and Apadore and Zainol (2014) reveal that the extent of corporate disclosure in Malaysia is dominated by ownership concentration, audit quality, board independence, CEO duality, board size and the presence of external auditors. Alternatively, based on a study by Haniffa and Cooke (2002), the results show that only two corporate governance characteristics, which are a family member on the board and chairperson are a non-executive director, are negatively correlated with the voluntary disclosure practices of both financial and non-financial information in the annual reports of Malaysian listed corporations. Regarding the previous finding, it has been confirmed by a study by Akhtaruddin et al. (2009) which remarks that family control has a negative effect on the extent of voluntary disclosure in Malaysia. Furthermore, the result also highlights that there is a significant positive correlation between voluntary disclosure and board size, the proportion of independent non-executive directors on the board and amount of outside ownership. Similarly, Utama (2012) also found that companies with medium block-holder ownership (between $20.1 \%-50 \%$ ) are likely to disclose less information than companies with low block-holder ownership (less than or equal 20\%) while companies with high block-holder ownership (greater than 50\%) generally provides a high level of information disclosure. Based on the evidence, it has been confirmed that block-holder ownership is significantly impacted on disclosure level of a company in Indonesia.

Together with a study of Luo et al. (2006), the finding is still consistent with the previous results by indicating that the level of voluntary disclosure in Singapore is significantly and positively related to high management ownership and outside block-holder ownership. Again, Ghazalia and Weetman (2006) also conclude that director ownership has a vital role in transforming the extent of voluntary disclosure, but government ownership is insignificant with corporate disclosure practices in Malaysia. However, the result appears to contradict another empirical study conducted in Malaysia. Htay et al. (2011) reveal that the relationship between director ownership and the extent of risk management information disclosure is highly statistically significant, with the negative sign while the proportion of independent non-executive directors is found to have a positive significant impact. Supported by the practices of a firm in Singapore, Eng, and Mak (2003) claim that an increasing number of outside directors and managerial ownership are negatively associated with voluntary disclosure while the role of government ownership is positively influenced on disclosure practices. Based on a study by $\mathrm{Vu}$ (2012), the result still strongly points out that the association between voluntary disclosure practices and the proportion of independent directors on the board is significant and positive in Vietnam. However, the extent of voluntary disclosure is negative significant with a higher proportion of state ownership and managerial ownership. 
Similarly, Cheng and Courtenay (2006) who examine the influence of board composition on voluntary disclosure in Singapore also assert that the proportion of independent directors is significantly connected to the level of voluntary disclosure. In other words, Hieu and Lan (2015) point out that in Vietnam, there is a positive relationship between foreign ownership and the level of voluntary disclosure, indicating that companies with high foreign ownership will disclose more corporate information compared with companies with low foreign ownership. This finding is concurrent with a study of Craig and Diga (1998) which investigates corporate accounting disclosure in five countries in ASEAN: Indonesia, Malaysia, Philippines, Singapore, and Thailand. The result finds that foreign ownership has a positive significant correlation with financial information disclosure at a significant level of 0.05 .

As briefly reviewed, it is obvious that the existing solid evidence acknowledging the success (or failure) of the significant improvements in promoting good corporate cultures in ASEAN is still limited while existing literature has been focused on the factors related to ownership structure and often ignored other governance variables. Consequently, this study aims to investigate current situation of corporate disclosure in Singapore and identify the factors contributing to the practices, with a particular focus on board compositions and audit committee characteristics.

\section{Theoretical framework}

Traditionally, a variety of theories have been employed to design an appropriate framework for allocating variables attributing to corporate disclosure practices. However, since this paper typically focuses on the attributes of corporate governance, only agency theory is applied as a benchmark to verify factors contributing to corporate disclosure practices.

\section{Agency theory}

Principally, businesses in a modern society have been forced to separate the role of the business owner out of management functions with a belief that this business structure might be more effective for reducing an inequality in access to organizational power and promoting sustainable development. That means shareholders (the principal), whether majority or minority, are unable to get involved directly with operational procedures, but they have to take an action through the agents or called as managers (Fauziah and Alhaji, 2012; Sharma, 2013). Nevertheless, in practice, such a model has rarely matched the expectation since a variety of problems might fruitfully occur in a workplace when the two parties have different opinions or conflicts of interest. Along with this matter, Jensen and Meckling (1976) proposed the "agency theory" to visible the interaction among stakeholders and managerial capitals. They suggest that a kinship among business actors (e.g. owners, managers, and investors) is strongly associated with corporate behaviors, resulting in business growth and increased profitability. In other words, it can be said that since self-interests of managers may potentially affect their decision-making quality, one of the most powerful applications that companies could apply to balance their passion with business goals is offering them a good compensation package. To do so, management will operate the business enthusiastically and make a good decision to increase market capitalization and maximize profit for investors, in return. Regarding this action, it is apparent that governance structures could enhance the relationship between shareholders and managers, resulting in fewer agency conflicts. 
Hence, healthy companies are more likely to create a flavor platform which helps them to engage with outside financing and more competitive in the market (Watts and Zimmerman, 1990; An et al., 2011; Randoy and Nielsen, 2002).

As noted, it is clear that agency theory is an important framework for linking internal control systems with business activities. Hence, its notion would be adapted to enlarge an understanding on the linkage between corporate governance and disclosure practices in Singapore.

\section{Literature review}

\subsection{Corporate disclosure}

In general, the term "corporate disclosure" is regularly used to refer to a communication activity that managers utilize to connect with stakeholders. It can be broadly sub-divided into two dimensions: mandatory and voluntary. In terms of mandatory disclosure, it is regularly related to national rules and regulations which are set to determine minimum practices that every company must comply with, otherwise be immediately penalized by a regulatory authority. On the other hand, voluntary disclosure normally implies that supplementary actions (above the mandatory requirements that a company can choose to apply or not apply based on its current situation and future challenge) (Eng and Mak, 2003; Akhtaruddin, 2005; Barako et al., 2006; Hassan et al. 2009; Trang and Phuong, 2015).

\subsection{The frameworks of corporate disclosure in Singapore}

Singapore has been widely recognized as the most effective country in Asia in promoting good governance. However, the regulations of disclosure standards still reflect a diversity of legal heritages as exhibited in the below table:

Table 1. Laws and regulations related to corporate disclosure in Singapore

\begin{tabular}{|c|c|c|c|}
\hline Laws and Regulations & $\begin{array}{c}\text { The year of } \\
\text { announcement }\end{array}$ & $\begin{array}{c}\text { Type of } \\
\text { Enforcement }\end{array}$ & Regulatory Authorities \\
\hline $\begin{array}{l}\text { SGX's Corporate } \\
\text { Disclosure Policy }\end{array}$ & 2002 & $\begin{array}{c}\text { Mandatory } \\
\text { Requirement }\end{array}$ & Singapore Stock Exchange \\
\hline $\begin{array}{l}\text { Companies (Accounting } \\
\text { Standards) Regulations }\end{array}$ & $\begin{array}{c}2004 \\
\text { (Revised Edition) }\end{array}$ & $\begin{array}{c}\text { Mandatory } \\
\text { Requirement }\end{array}$ & $\begin{array}{c}\text { Accounting Standards } \\
\text { Council Singapore }\end{array}$ \\
\hline $\begin{array}{c}\text { The Company Act (Chapter } \\
50)\end{array}$ & $\begin{array}{c}2006 \\
\text { (Revised Edition) }\end{array}$ & $\begin{array}{c}\text { Mandatory } \\
\text { Requirement }\end{array}$ & Singapore Government \\
\hline $\begin{array}{c}\text { The Securities and Futures } \\
\text { Act (Chapter 289) }\end{array}$ & $\begin{array}{c}2006 \\
\text { (Revised Edition) } \\
\end{array}$ & $\begin{array}{c}\text { Mandatory } \\
\text { Requirement }\end{array}$ & Singapore Government \\
\hline $\begin{array}{l}\text { The Singapore Exchange } \\
\text { Listing Rules (Chapter 12) }\end{array}$ & $\begin{array}{c}\text { 2011, as amended } \\
\text { in } 2017\end{array}$ & $\begin{array}{c}\text { Mandatory } \\
\text { Requirement }\end{array}$ & Singapore Government \\
\hline $\begin{array}{c}\text { Singapore Code of } \\
\text { Corporate Governance }\end{array}$ & 2012 & $\begin{array}{l}\text { Mandatory } \\
\text { Requirement }\end{array}$ & $\begin{array}{c}\text { Monetary Authority of } \\
\text { Singapore (MAS) and } \\
\text { Singapore Stock Exchange }\end{array}$ \\
\hline
\end{tabular}

Source: Collected by the author 
According to the table 1 , it is also conspicuous the regulatory framework of corporate disclosure in Singapore has been shaped based on four legal sources: the company laws, the accounting standards, the securities regulations, and the corporate governance codes. Additionally, it is found that since the first enactment, the disclosure regulatory frameworks of Singapore have been constantly improved in both scope and intensity, to increase the efficiency of enforcement and response with the changes of global business environment.

\subsection{Corporate governance}

Theoretically, the term "corporate governance" is intricate to describe in details because it is a broad concept that encompasses multifaceted disciplines of social sciences together. It includes the notions of business administration, financial and accounting, law, psychology, and many of the others (Claessens and Yurtoglu, 2013). Regarding the pervasive arrangements, its definition is abundantly designed in the governance literature. For example, according to the OECD principles (1999), it recommends that corporate governance is procedures and processes according to which an organization is managed and structured. Supported by the study of Blair (1995), the evidence suggests that the external mechanisms including legal system, cultural framework, and institutional principle can be related to the internal applications such as the extent of corporate authorities, the persons who are in charge of the company, the governance structure, and the allocations between risks and return portfolios from the corporate activities. Together with the study conducted by Jensen and Meckling (1976) as well as Shleifer and Vishny (2007), the evidence also offer that corporate governance is an effective way to cope with the agency cost that arising from the conflicts among objectives of owner-shareholders and managers and establish institutions, policies, and procedures assure that the investors will get the benefits from their investment in return. As cited above, it can be concluded the that corporate governance is the strategies or techniques that an organization uses for organizing the management structures, defining the rights and responsibilities of the executives, controlling the procedures for making a decision; sharpening the fairness, accountability, responsibility, and transparency of a company; and attracting the long-term investment from the foreign investors.

Yet, besides a variety of the meanings in an empirical research study, the concept of corporate governance can be specifically explained into two main streams: the Anglo-American model and the Central European model. Generally, the Anglo-American model is widely applied in the UK, the US, Australia, Canada, New Zealand and several other countries. Its principles are relevant to an open system that is implicitly based on a wider diffusion of ownership, a well-developed of shareholder rights and responsibilities, a short-term equity financing, and an easy procedure for shareholders to interact with the key players, known as management and directors. On the other hands, the Central European model is notably introduced in Germany, Austria, Netherland, Scandinavia, France, Belgium, and among others. It is a closed system that is governed based on a highly concentrated ownership environment, a banking system that defines both the scope of participation and a movement of a corporation and a cross-holding of debt and equity. (Three Models of Corporate Governance from Developed Capital Markets, 2011; Naciri, 2008) 
To acquaint with the above statements, it can be interpreted that in businesses, several issues associated with asymmetric information might emerge from key players including business owners, the board of directors, and executive managers. With respect to this matter, the notion of corporate governance is generally implemented to rearrange the organizational structure, the authorized hierarchy, and the relationship with the stakeholders; in order to solve such a challenge and achieve sustainable development.

\subsection{The relationship between corporate governance and information disclosure}

Since the principle of information disclosure typically plays an important role in protecting investors' right and wealth, it has often been linked with the concept of corporate governance. With regard to this network, several studies have been conducted to identify interactions between these two concepts. The results of which reported that corporate disclosure can affect the quality of corporate governance as a mechanism to sharpen business lucidity and accountability. That is because it is beneficial to promote better governance and raise operational efficiencies. Subsequently, the firms with the high degree of disclosure quality always perform good practices in term of corporate governance. However, based on the other side of the connection, many pieces of evidence strongly pointed out that corporate governance quality also has an effect on the flow of information. As a result, firms with good health conditions trend to disclose more information than the ones with poor governance practices. Yet, the results also mentioned that because the outcomes of the differentiation of corporate governance characteristics can be implicitly transferred to a firm, a company's disclosure practices are, therefore, flexible in each area and the level of corporate disclosure practices in each firm are unparalleled as well (Craig and Diga, 1998; Alberti-Alhtaybat et al, 2012; Abdullah and Minhat, 2013; Eng and Mak, 2003).

Regarding the variations in the degree of corporate disclosure practices among companies; many questions are asked to find out the facts that why not all companies comply fully with the disclosure requirements or why some of them are willing to reveal more corporate information than the others. Under such puzzles, a lot of studies found that there are multiple governance factors involved in the decision to divulge or conceal corporate information, specifically if it is highly sensitive and confidential for internal users (Owusu-Ansah, 1998; Archambault \& Archambault, 2003; Barako, Hancock, \& Izan, 2006; Qu \& Leung, 2006; Galani, Alexandridis, \& Stavropoulos, 2011). More to the point, a study of Mandzila and Zéghal (2016) posits that the extent of corporate disclosure is driven by a firm's corporate governance attributes including board size, board independence, CEO duality and ownership structure. This evidence can be supported by a study of Fiori et al., (2016) which explores the effects of corporate governance on voluntary disclosure in the EU, debates that size of the board is positively correlated with the adoption of the integrated report, leading to greater disclosure practices. Similarly, a study of Al-Janadi, et al. (2013) also argues that the level of corporate disclosure will increase with a large number of non-executive directors and a high proportion of board size, implying that the role of independent directors could help to protect the shareholders' interests. 
Supported by Hashima et al., (2015), they summarize that board size and director independence are positively related to sustainability disclosure practices of Islamic Financial Institutions (IFIs) in Gulf Council Cooperation (GCC). Together with a study conducted by Yang et al. which analyzes the relationship between corporate governance and voluntary financial disclosure on social media in the UK, the result still confirms that earning disclosure had a significant and positive connection with larger board size, greater gender diversity, and higher board effectiveness. Then, the finding of Lim et al., (2007) also exhibits that the extent of voluntary information disclosure in Australia has a positively significant relationship with board composition. Additionally, the independence of the board members has been found to be significant with an increase in forward-looking information and strategic information. Alternatively, García-Meca and Sánchez-Ballesta (2010) also emphasize that in the countries where to provide a high standard of investor protection rights are appointed to the positive relationship between board independence and voluntary disclosure. Later, the result of Agyei-Mensah (2016) recommends that board independence has a significant effect on internal control information disclosure of listed companies in Ghana. According to Ho and Wong (2001), they record that the extent of voluntary disclosure in Hong Kong is positively related to an audit committee, but negatively correlated with the number of a family member on the board at a significant level of 0.05 . This result is consistent with the finding of Al-Shammari and Al-Sultan (2010) which proposes that there is a significantly and positively relationship between a voluntary of an audit committee and the extent of voluntary disclosure in Kuwait. Again, Aboagye-Otchere and Kwakye (2012) interpret that the existence of audit committee with a financial expert(s) is a significant positive correlation with the level of corporate disclosure.

\section{Hypothesis development}

As observed, it is apparent that a large number of governance structures are strongly connected to corporate disclosure practices. But, most prior studies have been focused on the relationship between ownership structure and corporate disclosure. Hence, this paper would simply observe the factors related to the board of directors and auditors, to provide a new insight to the theory. However, due to research limitation, only attractive variables that are sensitive with the time have been further considered based on the theoretical foundations and disclosure literature, in order to formulate relevant hypotheses.

\subsection{Board size}

Regarding agency theory, it is believed that an individual person often lacks knowledge to operate the business smoothly. As a result of this, a great team with diverse backgrounds is required to bring on adequate expertise, resulting in more accurate decision-making. Supporting this view, it is assumed that the large size of the board is one of the significant determinants to decide the effectiveness of operational processes including the information disclosure behavior of a firm. In conformity with this opinion, several studies have documented that board size significantly influences on the degree of corporate disclosure (Zainon et al., 2014; Al-Janadi et al., 2016; Mandzila and Zéghal, 2016). 
Most of them (e.g. Cheung et al., 2007; Akhtaruddin et al., 2009; Al-Janadi et al., 2013; Hashima et al., 2015; Fiori et al., 2016; Yang et al.) suggest that size of a board has a positive correlation with a decision of management to disclose or not disclose information, indicating that firms with a large board size are generally more willing to disclose corporate information to the stakeholders than the others. As supported by both theoretical insights and the harmonious signal from several empirical studies, it might be postulated that there could be a positive relationship between board size and disclosure practices in the Singapore context. As a result of this, the following hypothesis is proposed:

\section{H1: Board size is positively related to the extent of corporate disclosure in Singapore}

\subsection{Board independence}

Indeed, members of a board are roughly classified into two categories. First is an executive director who is a full-time employee of a company and generally responsible for daily operations and overall performance including key achievements, long-term investment, and stakeholder engagements. Second is an independent non-executive director who is not under the control of the employer and not is a part of management team. Hence, the person who is appointed to this position can remain independence and probably provide some good advice from the outsider perspective to reduce the risks of getting in wrong directions of the management's decision. With the different types of directors, agency theory suggests that a board with a high number of independent directors would be more effective in making a decision. Hence, non-executive directors are needed on the boards to monitor and control the actions of executive directors. Through this insight, it could be supported by multiple studies which argue that there is a significant connection between the proportion of non-executive directors and information disclosure practices (Apadore and Zainol, 2014; Agyei-Mensah, 2016; Al-Janadi et al., 2016; Mandzila and Zéghal, 2016; Ben-Amar and Zeghal).

Furthermore, Cheung et al. (2007); Huafang and Jianguo (2007); Lim et al. (2007); Akhtaruddin et al. (2009); Yuen et al. (2009); Chau and Gray (2010); García-Meca and Sánchez-Ballesta (2010); Htay et al. (2011); Vu (2012); Barros et al. (2013); Uyar et al. (2013); Hashima et al. (2015); and Scholtz and Smit (2015) have provided more concrete evidences to enlarge an understanding on the topic. They confirm that the responsibility of non-executive directors is positively associated to the level of corporate disclosure, indicating that an independent board has an ability to influence managers to voluntarily deliver some necessary information excess from the requirements. To be specific, Cheng and Courtenay (2006) declare that under a disclosure-based regulatory regime; firms with a high number of independent directors have a significantly higher level of voluntary disclosure. Together with Al-Janadi et al. (2013) who reveals that when directors are more dependent on making decisions and monitoring management, they are willing to the public the quality reports with accurate information. As aforementioned, it can be assumed that board independence is positively related to corporate disclosure practices in Singapore. Consequently, the following hypothesis is proposed:

H2: The proportion of independent non-executive directors on board has a positive association with the extent of corporate disclosure in Singapore 


\subsection{Board effectiveness}

In practice, board effectiveness depends on two main elements: an active board and a dedication of directors to operational activities. An active board often refers to the frequency of board meeting which is a necessary platform to carry out management functions. These include reviewing the completed tasks and updating a progress of the project, discussing critical issues and brainstorming to find the proper solution, determining a strategic plan and future direction of the company, informing the members about the changes in an organization, maintaining the connectivity between the leaders and so on. On the other hands, a dedication of directors to operational activities is ordinarily described by the number of directors' attendance at the board meetings. From these particular parameters, agency theory convinces that management ability is strongly related to board effectiveness. This means firms with more frequency board meeting usually have stronger internal control systems for safeguarding the interests of shareholders. So, the decisions made are more in line with the desired directions and opportunity for future growth. Similarly, firms that authorized persons regularly participate in the meetings typically have more opportunities to achieve business goals and receive additional benefits. That is because the main tasks of each director will be continuously followed up and rigorously assessed to minimize unpredicted risks and maintain the quality of expected results.

Furthermore, by working together as a supportive team, the members of the board can share their expertise and obtain professional coaching to handle a challenging situation, contributing to the successful outcomes. To interpret such correlations, Barros et al. (2013), who conducted a research in France during the period 2006-2009, found that the level of voluntary disclosure of non-financial listed companies has been increased due to board meeting frequency. Together with a study of Yang et al. which reveals that board performance is positively significant with the extent of information dissemination, proposing that firms with a high frequency of board meetings tend to disclose more information related to financial status and earnings management. As remarked, it is assumed that the extent of corporate disclosure in Singapore will be increased when a number of board meetings held in the year and a number of director participation rate is high. Along with this assumption, the two hypotheses are generated as follow:

H3a: The number of board meetings held during the year is positively correlated with the extent of corporate disclosure in Singapore

$H 3 b$ : There is a positive association between director participation rate and the extent of corporate disclosure in Singapore

\subsection{Gender diversity}

Based on a concept of agency theory, it is asserted that a more diverse board can lead to better decision making, contributing to higher earnings. However, since personalities including traits between men and women are typically distinct from each other, some of which could reflect in management behaviors such as leadership styles, decision-making processes, techniques to communicate with co-workers, working relationships with employees and so on. 
In this sense, it potentially highlights the fact that quality of the board has been shaped by the variety of characteristics. As observed by Yang et al., they insist that the extent of earning disclosure of public listed companies in the United Kingdom (UK) is positively significantly associated with gender diversity on the board of directors, indicating that female representation can potentially enhance the quality of corporate disclosure. According to the aforementioned, both theoretical background and disclosure literature support the fact that a number of women directors on the board is one of the key factors to induce the level of corporate disclosure. For this reason, the hypothesis is derived as follow:

H4: The proportion of women directors on the board has a positive related with the extent of corporate disclosure in Singapore

\subsection{CEO duality}

Regarding a study of Yuen et al. (2009); Apadore and Zainol (2014) and Mandzila and Zéghal (2016), empirical evidence promptly indicate that there is a relationship between CEO duality and disclosure practices. Furthermore, Haniffa and Cooke (2002); Eng and Mak (2003); Huafang and Jianguo (2007); Chau and Gray (2010); Al-Janadi et al. (2013) point out that CEO duality has a negative effect with the extent of corporate disclosure. It is obvious that these evidence are similar to the notion of agency theory which believes that firms with CEO duality would often create conflicts of interest in the workplace. With regard to this matter, it can be assumed that role of chairman and CEO could be one of the significant factors in determining the level of corporate disclosure. Hence, the following hypothesis is hypothesized as follow:

\section{H5: CEO duality is negatively linked to the extent of corporate disclosure Singapore}

\subsection{Audit committee independence}

In the literature, audit committee independence is normally considered as the number of independent non-executive directors on the audit committee. Agency theory suggests that outside directors could play an important role in monitoring transparency and accountability of a firm. As a result of this matter, it is expected that companies with more independence of audit committee members would more likely to engage in information disclosure. To support this argument, Ho and Wong (2001); Barako et al. (2006); Yuen et al. (2009); Al-Shammari and Al-Sultan (2010) and Barros et al. (2013) reveal that the level of corporate disclosure is positively related to the proportion of independent directors on the board. Therefore, the hypothesis is stated as follow:

H6: The proportion of independent non-executive directors on the audit committee has a positive connection with the extent of corporate disclosure in Singapore

\subsection{Audit committee effectiveness}

Agency theory believes that an active audit committee is more effective in monitoring management behaviors. Consequently, firms with a high number of audit committee meeting and audit committee participation rate are significantly connected to the higher level of corporate disclosure. 
This understanding is in agreement with a study of Aboagye-Otchere et al. (2012) and Apadore and Zainol (2014) which deploys that there is a relationship between the extent of disclosure practices and audit competency. As a result, it can be assumed that an effectiveness of audit committee is positively associated with corporate disclosure practices of corporations in Singapore. Regarding this expectation, the two hypotheses are formulated as follow:

H7a: The number of audit committee meeting held during the year is positively associated with the extent of corporate disclosure in Singapore

H7b: There is a positive association between audit committee participation rate and the extent of corporate disclosure in Singapore

\section{Research methodology}

\subsection{Sample and data}

This study aims to conduct a longitudinal analysis between the years 2011 and 2015. As a result of this, only a small number of samples are taken. All of them are drawn from the top 50 of Singapore's companies in 2014 in regard to the belief that their corporate disclosure practices should be held to a higher standard compared with other listed companies and could be the stereotypes for other firms, whether in the local regime or at the regional level. Nonetheless, because the activities including disclosure rules of the bank and insurance industry are not quite comparable with the others, they were automatically excluded from the list. Then, the remainder samplings were selected based on the following criteria:

(i) Annual reports from the year 2011 to 2015 must be publicly available online

(ii) Firms must have been listed on the Stock Exchange of Singapore during $2011-2015$

The final sample covers 22 listed companies over five year period (from 2011 to 2015), generating 110 observations for this study.

\subsection{ASEAN Disclosure Index}

This study used a self-constructed research instrument, namely the ASEAN Disclosure Index, to assess the extent of corporate disclosure in the ASEAN through the annual reports and other company filings such as financial reports, corporate governance reports, and corporate social responsibility reports. It is developed based on the requirements of the renewal ASEAN disclosure standards, consisting of 212 information items, with three attributes: financial information (76 items), non-financial information (68 items) and strategic information (68 items).

To evaluate the level of disclosure practices in the ASEAN, 1 code is assigned to every information item that was expressed on the company's documents and 0 if otherwise. Then, the total disclosure score is calculated by summing the value of each information category and converted to the ratio of the actual scores that were awarded to a company when requested information was disclosed to the total scores that are expected to earn. The formula of the aforementioned index is given as follows: 
ASEAN Disclosure Index $(\mathrm{ADI})=\frac{\sum_{i=1}^{n} d i}{n}$

Where:

- $\quad$ ASEAN Disclosure Index $(\mathrm{ADI})=$ the ratio of the actual scores that were awarded to a company when requested information was disclosed to the total scores that are expected to earn. It is ranged from 0 to 1 , meaning that if a firm disclosed all 212 items of information, it would receive a score of 1 , accounting for $100 \%$.

- $\mathrm{n}=$ the total number of items that could be disclosed, where $\mathrm{n} \leq 212$

- $\quad \mathrm{di}=$ the actual value that was awarded to a company when the requested information is disclosed (assigned as 1 if the item di is disclosed, and 0 otherwise)

\subsection{Statistical tool and measurement of variables}

Regarding the purpose, a multiple regression model with pooled ordinary least square (OLS) method was applied to analyze the panel data by neglecting the differences between cross-sectional and time-series effects. To estimate transfer functions with the dependent variable (as represented by the extent of corporate disclosure in Singapore), the predictors or better known as the independent variables were tested through EVIEWS 10. The analytical equations in the pooled form are as follow:

$$
\begin{aligned}
\mathrm{ADI}_{\mathrm{it}}= & \beta_{0}+\beta_{1} \text { BSIZE }_{i t}+\beta_{2} \text { BIND }_{i t}+\beta_{3} B M E E T_{i t}+\beta_{4} D P R_{i t}+\beta_{5} G^{G E N_{i t}}+ \\
& \beta_{6} D U A L_{i t}+\varepsilon_{i t} \\
\mathrm{ADI}_{\mathrm{it}}= & \beta_{0}+\beta_{1} A C I_{i t}+\beta_{2} A C M E E T_{i t}+\beta_{3} A C P R_{i t}+\varepsilon_{i t} \\
\mathrm{ADI}_{\mathrm{it}}= & \beta_{0}+\beta_{1} \text { BSIZE }_{i t}+\beta_{2} B I N D_{i t}+\beta_{3} B M E E T_{i t}+\beta_{4} D P R_{i t} \\
& \beta_{5} \text { GEN }_{i t}+\beta_{6} D U A L_{i t}+\beta_{7} A C I_{i t}+\beta_{8} A C M E E T_{i t}+\beta_{9} A C P R_{i t}+\varepsilon_{i t}
\end{aligned}
$$

Where $A D I_{i t}$ is the extent of corporate disclosure practices of a firm i in time $\mathrm{t} ; \beta_{0}$ is the constant term; $\beta_{i}$ is the parameter of the correlation; $B S I Z E_{i t}$ is the total size of the board; $B I N D_{i t}$ is the proportion of independent non-executive directors on board; $B M E E T_{i t}$ is the number of board meeting held during the year; $D P R_{i t}$ is the he average director participation rate; $G E N_{i j t}$ is the proportion of women on the board; $D U A L_{i t}$ is the dummy of duality of roles between the chairman and CEO of a firm; $A C I_{i t}$ is the proportion the of independent directors on the audit committee; ACMEET $i t$ is the number of audit committee meeting held during the year; $A C P R_{i t}$ is the average audit committee participation rate; $\varepsilon_{i t}$ is the error term; $\mathrm{i}$ is the $i$ th observation firm and $\mathrm{t}$ is the year of observation.

\section{Results}

\subsection{Descriptive analysis of independent variables}

Table 2 provides an overview of descriptive statistics for the selected variables in the multiple regression models. The results cover the pooled data from 22 listed companies in Singapore over the years 2011-2015 as present in the below table: 
Table 2. The summary result of descriptive analysis

\begin{tabular}{|c|c|c|c|c|c|c|c|c|}
\hline & Mean & Median & Maximum & Minimum & Std. Dev. & Skewness & Kurtosis & Jarque-Bera \\
\hline DSCORE & 0.606 & 0.599 & 0.741 & 0.509 & 0.053 & 0.401 & 2.518 & 4.015 \\
\hline F_DSCORE & 0.613 & 0.618 & 0.737 & 0.474 & 0.060 & -0.104 & 2.581 & 1.001 \\
\hline NF_DSCORE & 0.612 & 0.610 & 0.765 & 0.485 & 0.059 & 0.248 & 3.000 & 1.131 \\
\hline S_DSCORE & 0.593 & 0.588 & 0.735 & 0.471 & 0.061 & 0.195 & 2.317 & 2.835 \\
\hline BSIZE & 9.809 & 10.000 & 15.000 & 5.000 & 1.956 & -0.174 & 3.496 & 1.682 \\
\hline BIND & 0.625 & 0.631 & 0.917 & 0.333 & 0.165 & -0.199 & 2.131 & 4.185 \\
\hline BMEET & 6.236 & 5.500 & 18.000 & 4.000 & 2.726 & 2.284 & 9.495 & 288.989 \\
\hline DPR & 8.875 & 9.000 & 13.000 & 0.097 & 1.945 & -0.889 & 6.061 & 57.429 \\
\hline GEN & 0.077 & 0.083 & 0.364 & 0.000 & 0.082 & 0.827 & 3.319 & 12.998 \\
\hline DUAL & 0.136 & 0.000 & 1.000 & 0.000 & 0.345 & 2.119 & 5.491 & 110.784 \\
\hline ACI & 0.890 & 1.000 & 1.250 & 0.250 & 0.159 & -0.918 & 4.312 & 23.342 \\
\hline ACMEET & 4.527 & 4.000 & 9.000 & 2.000 & 1.029 & 2.210 & 9.363 & 275.110 \\
\hline ACPR & 3.708 & 3.800 & 5.000 & 2.250 & 0.621 & -0.267 & 2.623 & 1.955 \\
\hline
\end{tabular}

\subsection{Correlation analysis}

The correlation analysis always plays a significant role in the regression model because this can be the indicators to measure how independent variables impact dependent variable. As a result of this, it is used to analyze the relationship between each explanatory variables and dependent variable to explain the determinants of disclosure score as presented in table 3 :

Table 3. The summary result of correlation analysis

\begin{tabular}{|c|c|c|c|c|c|c|c|c|c|c|}
\hline & DSCORE & BSIZE & BIND & BMEET & DPR & GEN & DUAL & ACI & ACMEET & $\overline{\text { ACPR }}$ \\
\hline DSCORE & 1.000 & & & & & & & & & \\
\hline BSIZE & 0.102 & 1.000 & & & & & & & & \\
\hline BIND & -0.379 & -0.148 & 1.000 & & & & & & & \\
\hline BMEET & -0.101 & 0.194 & 0.276 & 1.000 & & & & & & \\
\hline DPR & 0.120 & 0.778 & -0.168 & 0.124 & 1.000 & & & & & \\
\hline GEN & -0.232 & 0.025 & 0.419 & 0.183 & 0.074 & 1.000 & & & & \\
\hline DUAL & 0.397 & -0.288 & -0.304 & -0.035 & -0.173 & -0.111 & 1.000 & & & \\
\hline ACI & -0.419 & 0.085 & 0.441 & 0.127 & -0.012 & 0.103 & -0.510 & 1.000 & & \\
\hline ACMEET & -0.051 & 0.269 & 0.052 & 0.318 & 0.207 & -0.038 & 0.002 & -0.121 & 1.000 & \\
\hline ACPR & 0.036 & 0.110 & 0.069 & 0.034 & 0.216 & 0.010 & -0.246 & 0.074 & 0.204 & 1.000 \\
\hline
\end{tabular}

The result found that there is a correlation coefficient between board size and director participation rate is higher than 0.7 . Hence, it can be implied that there is a multicollinearity problem between these variables. However, since they have a low correlation with the disclosure scores and they are expected to have an effect with information disclosure practices, both of them have still been included in the analytical model. Besides this pair, other relationships are in between low and moderate level, ranging from 0.002 to 0.510 in both negative and positive direction, indicating that independent variables do not suffer from the problem of multicollinearity. So, none of them have been removed from the list. 


\subsection{Panel regression analysis}

To eliminate the heteroskedasticity and multicollinearity problems, the regression result is estimated based on the robust standard errors of White as present in the below table:

Table 4. The summary result of panel regression analysis

\begin{tabular}{|c|c|c|c|c|c|c|c|c|}
\hline \multirow{2}{*}{ Variable } & \multirow{2}{*}{$\mathbf{H}$} & \multicolumn{2}{|c|}{ Model1 } & \multicolumn{2}{|c|}{ Model2 } & \multicolumn{2}{|c|}{ Model3 } & \multirow[t]{2}{*}{ Result } \\
\hline & & Coef. & Prob & Coef. & Prob & Coef. & Prob & \\
\hline $\mathbf{C}$ & & 0.588 & 0.000 & 0.736 & 0.000 & 0.624 & 0.000 & \\
\hline BSIZE & $\mathrm{H} 1$ & -0.005 & 0.136 & & & -0.007 & $0.018^{* *}$ & Accepted \\
\hline BIND & $\mathrm{H} 2 \mathrm{a}$ & -0.052 & 0.109 & & & -0.020 & 0.566 & Rejected \\
\hline BMEET & $\mathrm{H} 2 \mathrm{~b}$ & -0.001 & 0.561 & & & 0.000 & 0.932 & Rejected \\
\hline DPR & $\mathrm{H} 3$ & 0.001 & 0.663 & & & -0.001 & 0.752 & Rejected \\
\hline GEN & $\mathrm{H} 4$ & -0.076 & 0.176 & & & -0.099 & 0.065 & Rejected \\
\hline DUAL & H5 & -0.060 & $0.000 *$ & & & -0.053 & $0.014 * *$ & Accepted \\
\hline ACI & H6 & & & 0.147 & $0.000 *$ & 0.086 & $0.025 * *$ & Accepted \\
\hline ACMEET & $\mathrm{H} 7 \mathrm{a}$ & & & 0.006 & 0.087 & 0.009 & $0.022 * *$ & Accepted \\
\hline ACPR & $\mathrm{H} 7 \mathrm{~b}$ & & & 0.008 & 0.242 & 0.014 & $0.028 * *$ & Accepted \\
\hline \multicolumn{2}{|c|}{ R-squared } & \multicolumn{2}{|c|}{0.272} & \multicolumn{2}{|c|}{0.195} & \multicolumn{2}{|c|}{0.343} & \\
\hline \multicolumn{2}{|c|}{ Adjusted R-squared } & \multicolumn{2}{|c|}{0.230} & \multicolumn{2}{|c|}{0.172} & \multicolumn{2}{|c|}{0.284} & \\
\hline \multicolumn{2}{|c|}{ F-statistic } & \multicolumn{2}{|c|}{6.414} & \multicolumn{2}{|c|}{8.546} & \multicolumn{2}{|c|}{5.807} & \\
\hline \multicolumn{2}{|c|}{$\operatorname{Prob}(F-$-statistic) } & \multicolumn{2}{|c|}{0.000} & \multicolumn{2}{|c|}{0.000} & \multicolumn{2}{|c|}{0.000} & \\
\hline
\end{tabular}

*significant at $99 \%$ level, **significant at $95 \%$ level

Regarding the panel regression analysis, the result of the model 1, which is formulated to test the effect of the board of directors on information disclosure practices, shows that CEO duality is significant at $99 \%$ confidence level. The R-squared of this model is quite high, accounted for 0.272 . This means the entire set of variables can explain the variation in corporate disclosure practices around $27.20 \%$

For model 2, variables related to auditors covering audit committee independence (ACI), number of audit committee meetings held in the year (ACMEET), audit committee participation rate (ACPR) and quality of external auditors (BIG4) are tested. The finding from the regression estimation addresses that only variable ACI is statically significant at $99 \%$ level, with a positive direction. The R-squared of this model equals 0.195 , meaning that a set of auditors' variables can explain corporate disclosure practices only $19.50 \%$.

Model 3 includes all variables of the board of directors and auditors for testing the combined effect of corporate governance mechanisms on information disclosure practices. The result reveals that board size, audit committee independence, a number of audit committee meetings held in the year and a number of audit committee participation rates have a positive relationship with corporate disclosure practice at $95 \%$ level while CEO duality has a negative association. The R-squared of this equation equals to 0.343 , indicating that a whole set of independent variables can explain the variation in corporate disclosure practices around $34.30 \%$. 
As described above, it is obvious that model 3 obtains the highest $\mathrm{R}$-squared value. This means a full model is most suitable for explaining corporate disclosure practices in Singapore's context. Hence, the only result obtained from this model is considered for analysis and conclusion.

\section{Analysis and discussion}

For the hypothesis 1, the variable BSIZE is statistically significant at the level of 0.05 (p-value $=0.018$ ) with a negative coefficient of 0.007. Unexpectedly, the finding contradicts from previous studies, which generally support agency theory by demonstrating a positive relationship between board size and disclosure practices. However, it is in accordance with the stewardship theory which suggests that oversized board of directors provides a vested interest in the success of the business, leading to poor quality of management and decreased firm performance. Hence, it can be argued that a small board size is more effective in enhancing the quality of decision-making processes and reducing free-rider problems. With this insight, it is not surprising that the extent of corporate disclosure in Singapore has a negative relationship with board size. In other words, it can be said that the corporations in the Singapore countries tend to more disclose information when board size is small. As a result of this, hypothesis 1 is accepted, with a negative direction.

Hypothesis 2 is proposed to test the relationship between board independence and disclosure practices of the firms. The result suggests that there is no significant relationship between variable BIND and the level of corporate disclosure at $95 \%$ level ( $\mathrm{p}$-value $=0.566$ ).

This finding is against the traditional belief of agency theory which emphasizes a positive relationship between the two variables. Also, it is contrary to many prior studies which likely mention that firms with a high number of independent directors on the board often disclose more corporate information to the public (e.g. Cheung et al, 2007; Huafang and Jianguo, 2007; Lim et al., 2007; Akhtaruddinet al., 2009; Htay et al., 2011; Vu, 2012; Barros et al., 2013; Uyar et al., 2013). However, the result could be debated by a concept of stewardship theory which suggests that behavioral patterns of the management are subjected to the person desires. As a result of this, neither dependent nor independent directors might have a less impact on operational practices. This has been confirmed by a study by Aboagye-Otchere et al. (2012) which also conducted a research in developing countries, namely Ghana. The result of this study reveals that corporate board composition is not a supportive factor for enhancing the extent of corporate disclosure. With this evidence, it could be implied that board independence has no relationship with the level of corporate disclosure in Singapore as well. As a result of this, hypothesis 2 is rejected.

In terms of board effectiveness, the results show that the level of corporate disclosure in Singapore has no connection with a number of the board meetings held in the year ( $p$-value = 0.932 ) and director participation rate $(p$-value $=0.752)$ at a significant level of 0.05 . With these findings, it has implications for stewardship theory which asserts that directors attempt to work in response to self-motivation and shareholders' requirements. So, a number of the board meetings held in the year and number of directors participated in the meeting are not an important factor for determining the operational procedures and performance of the board. 
Under this circumstance, it is reasonable to claim that there is no relationship between director participation rate and the level of corporate disclosure in Singapore. Consequently, hypothesis $\mathrm{h} 3 \mathrm{a}$ and $\mathrm{h} 3 \mathrm{~b}$ are rejected.

Hypothesis 4 is carried out to estimate the effect of gender diversity on corporate disclosure practices. The result demonstrates that a different gender of board members has no significant relationship with the extent of corporate disclosure in Singapore (p-value $=0.065$ ). Regarding this finding, it can be supported by the stewardship theory which states that a variety of members on the board might not impact the board actions. As a result of this, it can be concluded that whether male or female directors would not influence on disclosure practices of a firm in Singapore. Therefore, hypothesis 4 is rejected.

According to the hypothesis 5, the result reports that variable DUAL is statistically significant at the significant level of 0.01 ( $\mathrm{p}$-value $=0.014$ ) with a negative correlation coefficient of 0.053 , indicating that the separation of position between chairman and CEO could impact on corporate disclosure of the firms in Singapore. This is consistent with agency theory which remarks that a separate leadership structure has the ability to contribute quality of the reports. Under this scheme, it can be asserted by Chau and Gray (2010); Apadore and Zainol (2014); and Mandzila and Zéghal (2016) who found an association between CEO duality and disclosure practices. Later, many researchers (e.g. Haniffa and Cooke (2002); Eng and Mak (2003); Huafang and Jianguo (2007); and Al-Janadi et al. (2013)) have found that firms, where Chairman and CEO are the same person, tend to have a lower level of corporate disclosure. As a result of this, it is reasonable to believe that there is a negative relationship between CEO duality and disclosure practices. In contrast, it can be said that CEO-Chairman separation could infer in a better quality of reporting. Hence, hypothesis 5 is accepted, with a negative direction.

With regard to audit committee independence, the results show that there is a positively significant relationship between the variable ACI and the extent of corporate disclosure at 95\% level ( $\mathrm{p}$-value $=0.025$ with a positive correlation coefficient of 0.086 ). This is in the line with a study by Aboagye-Otchere et al. (2012) which addresses that corporations in Ghana tend to disclose more corporate information when audit committee is independent. As a result of this, it can be said that a number of independent directors on the audit committee could dominate the level of corporate disclosure. According to this insight, it is can be referred that there is a positive relationship between audit commit independence and the level of corporate disclosure in Singapore. For this reason, hypothesis 6 is accepted.

Accoring to audit committee effectiveness, the results show that the variable ACMEET and ACPR is positively related to the extent of corporate disclosure at $95 \%$ level ( $p$-value $=0.022$ with a correlation coefficient of 0.009 for the variable ACMEET and $\mathrm{p}$-value $=0.028$ with a correlation coefficient of 0.014 for the variable ACPR). With this finding, it can be interpreted that firms in Singapore tend to more disclosure corporate information when the quality of audit committee is high. To support this matter, Apadore and Zainol (2014) reveal that there is a relationship between quality of audit committee and corporate disclosure practices in Singapore. 
Together, Aboagye-Otchere et al. (2012) emphasize that frequency of audit committee meetings is associated with increased level of corporate disclosure. As discussed, it can be accepted that corporate disclosure of firms in Singapore could be dominated by a number of audit committee meeting. Hence, hypothesis $7 \mathrm{a}$ and $7 \mathrm{~b}$ are accepted.

As debated above, it is clear that all variables related to audit committee characteristics, covering three variables: audit committee independence, a number of audit committee held in the year and a number of audit committee participation rate, are positively and statistically significant at $95 \%$ level. As a result of this, it can be concluded that audit committee is an important factor for enhancing the level of corporate disclosure in Singapore. Furthermore, the finding still points out that board size has a positive relationship with information disclosure practices at $95 \%$ level while CEO duality has a negative association with the extent of corporate disclosure at $95 \%$ level. According to the finding, indicating that board size and CEO duality could influence on the extent of corporate disclosure in Singapore as well, but with a different direction.

\section{Conclusion}

This paper aims to investigate the effects of corporate governance mechanisms on information disclosure practices in Singapore, with a particular focus on board composition and audit committee characteristics. In the analytical procedure, a multiple regression model was tested through EVIEWS 10 with an ordinary least squares (OLS) method in order to estimate the connection between the predictors and the dependent variable. An empirical result reports that all variables related to audit committee characteristics, covering three variables: audit committee independence, a number of audit committee held in the year and a number of audit committee participation rate, are positively and statistically significant at $95 \%$ level. As a result of this, it can be concluded that audit committee is an important factor for enhancing the level of corporate disclosure in Singapore. Furthermore, the finding still points out that board size has a positive relationship with information disclosure practices while CEO duality has a negative association with the extent of corporate disclosure, indicating that board size and CEO duality could influence on the extent of corporate disclosure in Singapore as well, but with a different direction. For other variables covering board independence, a number of board meetings, a number of director participation rates and gender diversity, no significant relationship was found.

As remarked, it is apparent that the results provide empirical evidence for the regulators who would like to enhance a flavor business environment in Singapore and this might be used as a reference for other developing countries within the same region. The paper also contributes to the literature on disclosure by offering some insight into the relationship between corporate governance mechanisms on information disclosure practices based on the Asia's developed country perspective. Furthermore, it is obvious that stewardship theory seems to be more powerful for explaining the phenomenon of corporate disclosure in Southeast Asia region. 


\section{Limitations}

There are two main limitations inherent in this study. First has criticized the lack of diversity of expected factors. As identified from the literature survey, numerous variables have been found to formalize the disclosure practices of a company. However, this paper focuses only on two determinants of corporate governance: board of directors and auditors. Hence, it is necessary to enlarge an understanding by testing with other corporate governance attributes such as ownership structure. Alternatively, a further research might include other groups of variables such as national characteristics, firm characteristics and so on in the next investigation. Second has been discussed about the bias of population. Because the representative sample was extracted from top 50 Listed Companies in 2014 of Singapore, both scope and size are restricted. Therefore, a future research should be conducted with randomly selected population, covering whether public or private, big or small, and profit or non-profit organizations.

\section{References}

Abdullah, M., \& Minhat, M. (2013). Corporate Disclosure Quality in Malaysia. International Journal of Education and Research, 1-14.

Agyei-Mensah, B. K. (2016). Internal control information disclosure and corporate governance: evidence from an emerging market. Corporate Governance, 79-95. https://doi.org/10.1108/CG-10-2015-0136

Akhtaruddin, M. (2005). Corporate mandatory disclosure practices in Bangladesh. International Journal of Accounting, 399-422. https://doi.org/10.1016/j.intacc.2005.09.007

Akhtaruddin, M., Hossain, M. A., Hossain, M., \& Yao, L. (2009). Corporate Governance and Voluntary Disclosure in Corporate Annual Reports of Malaysian Listed Firms. JAMAR, 1-20.

Alberti - Alhtaybat, L. V., Hutaibat, K., \& Al-Htaybat, K. (2012). Mapping corporate disclosure theories. Journal of Financial Reporting and Accounting, 73-94. https://doi.org/10.1108/19852511211237453

Al-Janadi, Y., Rahman, R. A., \& Alazzani, A. (2016). Does Government Ownership Affect Corporate Governance and Corporate Disclosure? Evidence from Saudi Arabia. Managerial Auditing Journal. https://doi.org/10.1108/MAJ-12-2015-1287

Al-Janadi, Y., Rahman, R. A., \& Omar, N. (2013). Corporate Governance Mechanisms and Voluntary Disclosure in Saudi Arabia. Research Journal of Finance and Accounting, 25-35.

Al-Shammari, B., \& Al-Sultan, W. (2010). Corporate governance and voluntary. International Journal of Disclosure and Governance, 262-280. https://doi.org/10.1057/jdg.2010.3

An, Y., Davey, H., \& Eggleton, I. R. (2011). Towards a comprehensive theoretical framework for voluntary IC disclosure. Journal of Intellectual Capital, 571-585. https://doi.org/10.1108/14691931111181733

Apadore, K., \& Zainol, S. S. (2014). Determinants of Corporate Governance and Corporate Performance among Consumer Product Industry in Malaysia: A Theoretical Model. International Journal of Academic Research in Accounting, Finance and Management Sciences, 159-165. 
Archambault, J. J., \& Archambault, M. E. (2003). A multinational test of determinants of corporate disclosure. The International Journal of Accounting, 173-194. https://doi.org/10.1016/S0020-7063(03)00021-9

Barako, D. G., Hancock, P., \& Izan, H. Y. (2006). Factors Influencing Voluntary Corporate Disclosure by Kenyan Companies. Corporate Governance, 107-125. https://doi.org/10.1111/j.1467-8683.2006.00491.x

Barros, C. P., Boubaker, S., \& Hamrouni, A. (2013). Corporate Governance And Voluntary Disclosure In France. The Journal of Applied Business Research, 561-578. https://doi.org/10.19030/jabr.v29i2.7657

Ben-Amar, W., \& Zeghal, D. (n.d.). Filing for Bankruptcy Protection, Governance Mechanisms, and Corporate Disclosure.

Blair, M. (1995). Ownership and Control: Rethinking Corporate Governance for the Twenty-First Century. Washington DC: The Brookings Institution.

Chau, G., \& Gray, S. J. (2010). Family ownership, board independence, and voluntary disclosure: Evidence from Hong Kong. Journal of International Accounting, Auditing, and Taxation, 93-109. https://doi.org/10.1016/j.intaccaudtax.2010.07.002

Cheng, E. C., \& Courtenay, S. M. (2006). Board composition, regulatory regime, and voluntary disclosure. International Journal of Accounting, 262-289. https://doi.org/10.1016/j.intacc.2006.07.001

Cheung, S. Y.-L., Connelly, J. T., Limpaphayom, P., \& Zhou, L. (2007). Determinants of Corporate Disclosure and Transparency: Evidence from Hong Kong and Thailand. Controversies in International Corporate Responsibility, 313-342.

Claessens, S., \& Yurtoglu, B. B. (2013). Corporate governance in emerging markets: A survey. Emerging Markets Review, 1-33. https://doi.org/10.1016/j.ememar.2012.03.002

Craig, R., \& Diga, J. (1998). Corporate Accounting Disclosure in ASEAN. Journal of International Financial Management and Accounting, 246-274. https://doi.org/10.1111/1467-646X.00039

Eng, L., \& Mak, Y. (2003). Corporate governance and voluntary disclosure. Journal of Accounting and Public Policy, 325-345. https://doi.org/10.1016/S0278-4254(03)00037-1

Fauziah, W. Y., \& Alhaji, I. A. (2012). The Insight of Corporate Governance Theories. Journal of Business \& Management, 52-63.

Fiori, G., Donato, F. d., \& Izzo, M. F. (2016). Exploring the Effects of Corporate Governance on Voluntary Disclosure: An Explanatory Study on the Adoption of Integrated Report. Performance Measurement Measurement and Management Control: Contemporary Issues, 83-108. https://doi.org/10.1108/S1479-351220160000031003

Galani, D., Alexandridis, A., \& Stavropoulos, A. (2011). The association between the firm characteristics and corporate mandatory disclosure: The case of Greece. International Scholarly and Scientific Research \& Innovation, 286-292.

García-Meca, E., \& Sánchez-Ballesta, J. P. (2010). The Association of Board Independence and Ownership Concentration with Voluntary Disclosure: A Meta-analysis. European Accounting Review, 603-627. https://doi.org/10.1080/09638180.2010.496979 
Ghazalia, N. A., \& Weetman, P. (2006). Perpetuating traditional influences: Voluntary disclosure in Malaysia following the economic crisis. Journal of International Accounting, Auditing, and Taxation, 226-248. https://doi.org/10.1016/j.intaccaudtax.2006.08.001

Haniffa, R. M., \& Cooke, T. E. (2002). Culture, Corporate Governance, and Disclosure in Malaysian Corporations. ABACUS, 317-349. https://doi.org/10.1111/1467-6281.00112

Hashima, F., Mahadia, N. D., \& Amrana, A. (2015). Corporate Governance and Sustainability Practices in Islamic Financial Institutions: The Role of Country of Origin. International $\begin{array}{lllll}\text { Accounting } \quad \text { and } & \text { Business }\end{array}$ https://doi.org/10.1016/S2212-5671(15)01129-6

Hassan, O. A., Romilly, P., Giorgioni, G., \& Power, D. (2009). The value relevance of disclosure: Evidence from the emerging capital market of Egypt. The International Journal of Accounting, 79-102. https://doi.org/10.1016/j.intacc.2008.12.005

Hieu, P. D., \& Huong Lan, D. T. (2015). Factors Influencing the Voluntary Disclosure of Vietnamese Listed Companies. Journal of Modern Accounting and Auditing, 656-676.

Ho, S. S., \& Wong, K. S. (2001). A study of the relationship between corporate governance structures and the extent of voluntary disclosure. Journal of International Accounting, Auditing \& Taxation, 139-156. https://doi.org/10.1016/S1061-9518(01)00041-6

Htay, S. N., Rashid, H. M., Adnan, M. A., \& Meera, A. K. (2011). Corporate Governance and Risk Management Information Disclosure in Malaysian Listed Banks: Panel Data Analysis. International Review of Business Research Papers, 159-176.

Huafang, X., \& Jianguo, Y. (2007). Ownership structure, board composition, and corporate voluntary disclosure: Evidence from listed companies in China. Managerial Auditing Journal, 604 - 619. https://doi.org/10.1108/02686900710759406

Jensen, M. C., \& Meckling, W. H. (1976). Theory of the firm: Managerial behavior, agency cost, and ownership structure. Journal of Financial Economics, 305-360. https://doi.org/10.1016/0304-405X(76)90026-X

Lim, S., Matolcsy, Z., \& Chow, D. (2007). The Association between Board Composition and Different Types of Voluntary Disclosure. European Accounting Review, 555-583. https://doi.org/10.1080/09638180701507155

Luo, S., Courtenay, S. M., \& Hossain, M. (2006). The effect of voluntary disclosure, ownership structure and proprietary cost on the return-future earnings relation. Pacific-Basin Finance Journal, 501-521. https://doi.org/10.1016/j.pacfin.2006.02.002

Mandzila, E. E., \& Zéghal, D. (2016). Content Analysis Of Board Reports On Corporate Governance, Internal Controls And Risk Management: Evidence From France. The Journal of Applied Business Research, 637-648. https://doi.org/10.19030/jabr.v32i3.9668

Naciri, A. (2008). Corporate Governance Around the World. New York: Routledge. https://doi.org/10.4324/9780203930670

Owusu-Ansah, S. (1998). The impact of corporate attributes on the extent of mandatory disclosure and reporting by listed companies in Zimbabwe. The International Journal of Accounting, 605-631. https://doi.org/10.1016/S0020-7063(98)90015-2 
Qu, W., \& Leung, P. (2006). Cultural impact on Chinese corporate disclosure - a corporate governance perspective. Chinese corporate disclosure, 241-264. https://doi.org/10.1108/02686900610652991

Randoy, T., \& Nielsen, J. (2002). Company Performance, Corporate Governance, and CEO Compensation in Norway and Sweden. International Business, 57-81.

Scholtz, H., \& Smit, A.-R. (2015). Factors influencing corporate governance disclosure of companies listed on the Alternative Exchange (AltX) in South Africa. South African Journal of Accounting Research, 29-50. https://doi.org/10.1080/10291954.2015.999471

Sharma, N. (2013). Theoretical Framework for Corporate Disclosure Research. Asian Journal of Finance \& Accounting, 183-196. https://doi.org/10.5296/ajfa.v5i1.3210

Shleifer, A., \& Vishhny, R. W. (1997). A survey of corporate governance. The journal of finance, 737-783. https://doi.org/10.1111/j.1540-6261.1997.tb04820.x

Three Models of Corporate Governance from Developed Capital Markets. (2011, January). Retrieved April 15, 2014, from Emerging Markets ESG: https://www.emergingmarketsesg.net/esg/wp-content/uploads/2011/01/Three-Models-of-Corp orate-Governance-January-2009.pdf

Trang, V. T., \& Phuong, N. C. (2015). The Disclosure in the Annual Reports by the Listed Companies on the Ho Chi Minh Stock Exchange. International Journal of Business and Social Science, 117-126.

Utama, C. A. (2012). Company Disclosure In Indonesia: Corporate Governance Practice, Ownership Structure, Competition And Total Assets. Asian Journal of Business and Accounting, 75-108.

Uyar, A., Kilic, M., \& Bayyurt, N. (2013). association between firm characteristics and corporate voluntary disclosure: Evidence from Turkish listed companies. Intangible Capital, 1080-1112.

Vu, K. B. (2012). Determinants of voluntary disclosure for Vietnamese listed firms.

Watts, R., \& Zimmerman, J. (1990). Positive accounting theory: a ten-year perspective. The Accounting Review, 131-156.

Yang, J. H., Liu, S., \& Zhou, D. (n.d.). Voluntary financial disclosure on social media: Does corporate governance matter?

Zainon, S., Atan, R., \& Wah, Y. B. (2014). An empirical study on the determinants of information disclosure of Malaysian non-profit organizations. Asian Review of Accounting, 35-55. https://doi.org/10.1108/ARA-04-2013-0026 